\title{
Measurement of Sustainability Learning For Computer Users in the Bureau Administration Center of Unimed
}

\author{
Syamsul Gultom \\ Faculty of Sport and Science, Medan State University, Indonesia
}

\begin{abstract}
This study was conducted in descriptive research design that describes the level of fatigue for computer users at the Bureau of Unimed Administration Center and Computer Center. The populations of the study were Employees of civil servants and honorary workers who used computers in the Building Administration Center of Unimed were numbered 78 peoples. The sampling technique was used purposive. As for inclusion criteria in this research that was computer user in the Administrative Bureau of Academic and Student Affairs were 19 respondents, Bureau of Public Administration and Finance were 24 respondents, and Administrative Bureau of Planning and Information Systems were 14 and Computer Center were 21 respondents who used computers over 4 hours 1 day. This study was aimed to know fatigue rate for computer users by using the measurement fatigue tool using KAUPK2 (Kuesioner Alat Ukur Perasaan Kelelahan Kerja/Work Fatigue Measurement Questionnaire). The fatigue level measurements were performed to identify the types of fatigue experienced by computer user employees at the Bureau of Unimed Administration Center and Computer Center which subsequently found an alternative solution to the reduction and prevention of fatigue experienced by computer users. Based on the research results of fatigue rate experienced by employees of computer users in Unimed was low category. The lowest measurement of fatigue level was type 8 (feel not diligent in carrying out the work) and Type fatigue number 15 (feel tired before work) was 1,3\%. The highest level of fatigue measurements was found in type 17 fatigues (feel anxious about something).
\end{abstract}

Keywords: Fatigue, KAUPK2, Computer Users

\section{Introduction}

Computer is one of the technological developments. The use of computers around the world has increased over time. Based on a survey in the United States, the average working time used to work with computers was 5.8 hours or $69 \%$ of the total 8 working hours (Wasisto, 2005). It is estimated that nearly 60 million people suffer from global Computer Vision Syndrome (CVS) and about one million new cases occur each year (Sen and Richardson, 2007). Approximately $70 \%$ of computer workers in the world experience vision problems and a very sharp increase (Blehm et al., 2005). In addition to CVS, other disorders found in computer users were neck pain defined in the study as the natural pain from the base of the skull spread to the upper back of the shoulder blade (J Can CA, 2008). According to Medical Officer of Health RI (2005), $40.5 \%$ of workers in Indonesia have health problems related to their work and among them are members of skeletal muscle as much as $16 \%$ (Tana 2009). Based on data in Indonesia General Hospital of Central Lampug District, musculoskeletal disease groups including back pain was ranked as the top ten most outpatient diseases. During the year 2006 there were 32 patients treated with muscle pain complaints, whereas in 2007 there was more than triple jump. Most of them suffer from rheumatoid arthritis and partly back pain. During January to March 2008 there were about 40 patients with the same pain complaints and most of the sufferers were employees who spent much time in office as computer operators (Sumekar, 2008).

Wardhana research cited by laurensia (2004) in company that many use computers that is ausransi company obtained data of muscle pain complaints caused by computer usage as follows: $25 \%$ employees complained of shoulder pain, $19 \%$ of employees suffered wrist pain, $15 \%$ of employees experiencing pain on the neck regularly, $14 \%$ of employees complain of back pain. Other results were obtained in many computer-based tourist bureaus, giving muscle pain complaints data as follows: $54 \%$ of employees complained of shoulder pain, $32 \%$ of employees felt pain in the lower back, $24 \%$ of employees experienced leg pain, $18 \%$ of employees suffered neck pain , 6\% of employees say headache, arms and wrists.

Based on the initial survey conducted on several employees at the Bureau of Unimed Administration Center and Computer Center was obtained information that they most experienced fatigue of the eyes, neck, shoulders, back, waist and mental fatigue. Employee work starts from at 08.00 16.00 WIB and given one break time is at 12:00 to $14: 00$ $\mathrm{pm}$. While carrying out day-to-day tasks and other additional tasks, the time for rest will be shorter and the end of the job will be longer than the time specified.

\section{Research Method}

This study was conducted in descriptive research design that describes the level of fatigue for computer users at the Bureau of Unimed Administration Center and Computer Center. The populations of the study were Employees of civil servants and honorary workers who used computers in the Building Administration Center of Unimed were numbered 78 peoples. The sampling technique was used purposive. As for inclusion criteria in this research that was computer user in the Administrative Bureau of Academic and Student Affairs were 19 respondents, Bureau of Public Administration and Finance were 24 respondents, and Administrative Bureau of Planning and Information Systems were 14 and Computer Center were 21 respondents who used computers over 4 hours 1 day. 


\section{International Journal of Science and Research (IJSR) \\ ISSN (Online): 2319-7064}

Index Copernicus Value (2015): 78.96 | Impact Factor (2015): 6.391

\section{Result and Discussion}

\subsection{Result}

Achievements of the results of research was conducted in 4 (four) units of the section namely the Bureau of Public Administration and Finance, the Administrative Bureau of Academic and Student Affairs, Central Bureau and Information Systems and Computer Center whose job was to use a computer. The first activities undertaken during the implementation of the research were: (1) conduct a coordination meeting between the researcher and the unit to be researched and the team, (2) conduct the implementation time meeting for the first year and division of tasks and technical implementation of the research; (3) develop an instrument to analyze the level of complaints experienced by employees Sample, (4) analysis of experimental test results, (5) implementation of research (data collection at 4 (four) locations in Unimed environment, namely The Bureau of Public Administration and Finance, The Administration Bureau of Academic and Student Affairs, Central Bureau and Information Systems, and Computer Center, (6) report preparation.

A lot of sample from the Administrative Bureau of Academic and Student Affairs counted 19 people, the Bureau of Public Administration and Finance counted 24 people, Central Bureau and Information Systems counted 14 people, and Computer Center counted 21 people. The results of the implementation of the research questionnaire conducted generated data with details as follows:

Table 1: Results of Measurement of Fatigue Rate on Computer Users at Administration Center and Computer Center Unimed

\begin{tabular}{|c|c|c|c|}
\hline \multirow{2}{*}{ No } & \multirow{2}{*}{ Type of Tired } & \multicolumn{2}{|c|}{$\begin{array}{c}\text { Percentage of } \\
\text { Respondents } \\
\text { Answer }\end{array}$} \\
\cline { 2 - 4 } & & Yes & No \\
\cline { 2 - 4 } & & $7,7 \%$ & $92,3 \%$ \\
\hline 1 & Feel Hard to Think & $3,8 \%$ & $96,2 \%$ \\
\hline 2 & Feel Tired to Talk & $14,1 \%$ & $85,9 \%$ \\
\hline 3 & Feeling Nervous Facing Something & $5,1 \%$ & $94,9 \%$ \\
\hline 4 & Feel Never Concentrate In Facing Something & $5,7 \%$ & $92,3 \%$ \\
\hline 5 & Feeling No Attention to Something & $74,1 \%$ & $85,9 \%$ \\
\hline 6 & Feeling Tend to Be Forgetting Against & 14,9 \\
\hline 7 & Something & $10,3 \%$ & $89,7 \%$ \\
\hline 8 & Feeling Inconsistent In Implementing Work & $1,3 \%$ & $98,7 \%$ \\
\hline 9 & Feeling Reluctant to Look At Others' Eyes & $16,7 \%$ & $83,3 \%$ \\
\hline 10 & Feel Reluctant to Work Hardly & $5,1 \%$ & $94,9 \%$ \\
\hline 11 & Feeling Not Calm in Working & $12,8 \%$ & $87,2 \%$ \\
\hline 12 & Feeling Tired All of his/her Body & $21,8 \%$ & $78,2 \%$ \\
\hline 13 & Feel Slow Acting & $6,4 \%$ & $93,6 \%$ \\
\hline 14 & Feeling Not Strong More Walking & $2,6 \%$ & $97,4 \%$ \\
\hline 15 & Feeling Tired Before Working & $1,3 \%$ & $98,7 \%$ \\
\hline 16 & Feeling Power of Thought Decreased & $17,9 \%$ & $82,1 \%$ \\
\hline 17 & Feeling Anxious about Something & $24,4 \%$ & $75,6 \%$ \\
\hline
\end{tabular}

\subsection{Discussion}

1) From the results of the measurements of fatigue that feel hard to think is the Administrative Bureau of Academic and Student Affairs with 0\% percentage Yes and No
$100 \%$, the Bureau of Public Administration and Finance with percentage Yes $12.5 \%$ and No $87.5 \%$, Central Bureau and Information Systems with yes $7.1 \%$ and answer $92.9 \%$, computer center by answering Yes $9.5 \%$, No 90.5 .

2) From fatigue measurement result that is tired of talking that is Administrative Bureau of Academic and Student Affairs with percentage $0 \%$ Yes and No $100 \%$, the Bureau of Public Administration and Finance with percentage Yes $8.3 \%$ and answer No $91.7 \%$, Central Bureau and Information Systems with Yes answer was $7.1 \%$ and No was t $92.9 \%$, Computer Center by answering Yes $0 \%$, No $100 \%$

3) From the measurement result of fatigue that feel nervous when facing Something that is the Administrative Bureau of Academic and Student Affairs with percentage Yes 5.3\% and No 94.7\%, the Bureau of Public Administration and Finance with percentage Yes $12.5 \%$ and No $91.7 \%$, Central Bureau and Information Systems with Yes $7.1 \%$ and No 92.9\%, Computer Center with Yes $28.6 \%$, No $71.4 \%$.

4) From the result of fatigue measurement that felt never concentrate in facing something that is the Administrative Bureau of Academic and Student Affairs with percentage Yes 5.3\% and No 94.7\%, the Bureau of Public Administration and Finance with percentage Yes $4.2 \%$ and No $95.8 \%$, Central Bureau and Information Systems with Yes $14.4 \%$ answer and No $85.7 \%$, Computer Center with answer Yes 28.6\%, No 71.4\%.

5) From fatigue measurement results that do not have attention to something that is the Administrative Bureau of Academic and Student Affairs with percentage Yes $0 \%$ and No 100\%, the Bureau of Public Administration and Finance with percentage Yes $4.2 \%$ and No $95.8 \%$, Central Bureau and Information Systems with answer Yes $21.4 \%$ and No 78.6\%. Computer Center with answer Yes 9.5\%, No 90.5\%.

6) From fatigue measurement result that tend to forget to something that is the Administrative Bureau of Academic and Student Affairs with percentage Yes $10.5 \%$ and No $89.5 \%$, the Bureau of Public Administration and Finance with percentage Yes $20.8 \%$ and No $79.2 \%$, Central Bureau and Information Systems with answer Yes $21.4 \%$ and No $78.6 \%$, Computer Center With Yes $14.3 \%$, No 85.7\%.

7) From the results of measurement of fatigue that feel less self-confidence that is the Administrative Bureau of Academic and Student Affairs with percentage 0\% Yes and No 100\%, the Bureau of Public Administration and Finance with percentage Yes $12.5 \%$ and No $87.5 \%$, Central Bureau and Information Systems with Yes $21.4 \%$ and No $78.6 \%$, Computer center with answer Yes $19 \%$, No $81 \%$.

8) From the measurement result of fatigue that feel not diligent in doing the job that is the Administrative Bureau of Academic and Student Affairs with percentage Yes 0\% and No 100\%, the Bureau of Public Administration and Finance with percentage Yes $4.2 \%$ and No $95.8 \%$, Central Bureau and Information Systems with yes $0 \%$ and No100\% answer, Computer Center with yes $0 \%$ answer, No $100 \%$.

9) From the measurement result of fatigue that feel reluctant to look people eye that is the Administrative 


\section{International Journal of Science and Research (IJSR) \\ ISSN (Online): 2319-7064}

Index Copernicus Value (2015): 78.96 | Impact Factor (2015): 6.391

Bureau of Academic and Student Affairs with percentage Yes 5.3\% and No 94.7\%, the Bureau of Public Administration and Finance with percentage Yes $16.67 \%$ and No $83.3 \%$, Central Bureau and Information Systems with answer Yes $31.4 \%$ and No 78.6\%, Computer Center With answer Yes $23.8 \%$, No 76.2\%.

10) From the results of fatigue measurements that feel reluctant to work nimble ie the Administrative Bureau of Academic and Student Affairs with $0 \%$ the Administrative Bureau of Academic and Student Affairs Yes percentage and No $100 \%$, the Bureau of Public Administration and Finance with $0 \%$ Yes percentage and No 100\%, Central Bureau and Information Systems with Yes $0 \%$ answer and No $100 \%$, Computer Center with Answered Yes 19\%, No 81\%.

11) From the measurement of fatigue that feel uncomfortable in work that is The Administration Bureau of Academic and Student Affairs with $0 \%$ Yes percentage and No $100 \%$, The Bureau Of Public Administration and Finance with percentage Yes $4.2 \%$ and No $95.8 \%$, Central Bureau and Information Systems with Yes $7.1 \%$ answer and No $92.9 \%$, Computer Center with answer Yes $38.1 \%$, No $61.9 \%$.

12) From fatigue measurement result of whole body that Is The Administration Bureau of Academic and Student Affairs with percentage Yes $10.5 \%$ and No $89.5 \%$, The Bureau of Public Administration and Finance with percentage Yes 25\% and No 75\%, Central Bureau and Information Systems with answer Yes $21.4 \%$ and No $78.6 \%$, Computer Center with answered Yes $28.6 \%$, No $71.4 \%$.

13) From the measurement result of fatigue that feels sluggish that is The Administration Bureau of Academic and Student Affairs with percentage Yes 5.3\% and No 94.7\%, The Bureau of Public Administration and Finance with percentage Yes $4.2 \%$ and No 95.8\%, Central Bureau And Information Systems with Yes $14.3 \%$ answer and No $85.7 \%$, Computer Center by answering Yes $4.8 \%$, No $95.2 \%$.

14) From the measurement of fatigue that feel no longer running again that is The Administration Bureau of Academic and Student Affairs with percentage Yes 0\% and No $100 \%$, The Bureau of Public Administration and Finance with percentage Yes $8.3 \%$ and No 91.7\%, Central Bureau and Information Systems with Yes 0\% answer and No $14 \%$, Computer Center by saying Yes $0 \%$, No $100 \%$.

15) From the measurement of fatigue that felt before work is tired that is The Administration Bureau of Academic and Student Affairs with $0 \%$ Yes percentage and answer not $100 \%$, The Bureau of Public Administration and Finance with $0 \%$ Yes percentage and No 100\%, Central Bureau and Information Systems with Yes 0\% answer and No $14 \%$, Computer Center with answer Yes $4.8 \%$, No $95.2 \%$.

16) From the measurement of fatigue that felt lowered thinking that is The Administration Bureau of Academic and Student Affairs with percentage of $21.1 \%$ Yes and No $78.9 \%$, The Bureau of Public Administration and Finance with percentage Yes $25 \%$ and No $75 \%$, Central Bureau and Information Systems with Yes $14.3 \%$ and No $85.7 \%$, Computer Center with Answer Yes 9.5\%, No $90.5 \%$.
17) From the measurement of fatigue that feels anxious to something that is The Administration Bureau of Academic and Student Affairs with percentage Yes $36.8 \%$ and No $63.2 \%$, The Bureau of Public Administration and Finance with percentage Yes 29.2\% and No $70.8 \%$, Central Bureau And Information Systems with Yes $14.3 \%$ and No $85.7 \%$, Computer Center with Answered Yes $14.3 \%$, No $85.7 \%$.

\section{Conclusions and Suggestions}

\subsection{Conclusions}

1) From the measurement result of fatigue level of computer user by using KUPK2 (Kuesioner Alat Ukur Perasaan Kelelahan Kerja/Work Fatigue Measurement Questionnaire) then all kind of fatigue experienced by the respondents there are about $90 \%$ who do not experience fatigue and $10 \%$ who experience fatigue.

2) The level of fatigue experienced by employees of computer users in Unimed was low category.

3) The lowest level of fatigue measurement is the type of fatigue (Feeling Not Diligent in Implementing Work) that is as much as $1.3 \%$ answered Yes and No $98.7 \%$.

4) Measurement of the highest level of fatigue is the type of fatigue (Feeling Anxious Against Something) that is as much as $24.4 \%$ answered Yes and No $75.6 \%$

\subsection{Suggestions}

Based on the results of fatigue measurement studies using KUPK2, the results of measurement of very low level of defeat in all types of fatigue, therefore the measurement of later fatigue level is recommended using Bourdon Wiersma test because Bourdon Wiersma is a more appropriate test tool used to measure fatigue (objectively) Activities or jobs that are more mental

\section{References}

[1] Blehm C, Vishnu S, Khattak A, Mitra S dan Yee RW (2005). Computer vision syndrome: a review. Surv. Ophthalmol. 50(3): 253-262.

[2] Can, J., CA. 2008. A Literature review of neck pain associated with computer use: Public health implications, 52(3): 161-168.

[3] Departemen Kesehatan R.I. (2005). Rencana Strategi Departemen Kesehatan. Jakarta: Depkes RI.

[4] Grandjean, 1993, Fitting the Task to t e Human 4th edition, Taylor \& Francis Inc

[5] London.

[6] Laurensia, B. 2004. Gambaran Ergonomi dan Dampaknya Terhadap Kesehatan Tenaga Kerja Kasir di Pasar Swalayan Metro Medan Plaza. Skripsi: Universitas Sumatera Utara.

[7] Manuaba, A. 1998, Penerapan Ergonomi Kesehatan Kerja di Rumah Tangga, Bunga Rampai Ergonomi, Denpasar, Program Studi ErgonomiFisiologi Kerja Universitas Udayana.

[8] Pulat, B.M, 1992, Fundamentals of Industrial Ergonomics.Hall International. Englewood Cliffs. New Jersey. USA. 


\section{International Journal of Science and Research (IJSR) \\ ISSN (Online): 2319-7064}

Index Copernicus Value (2015): 78.96 | Impact Factor (2015): 6.391

[9] Sen A, Richardson S. 2007 . A study of computerrelated upper limb discomfort and computer vision syndrome. J. Hum. Ergol (Tokyo). 36(2): 45-50.

[10] Sumekar, DW., Deny, N. 2008. Nyeri Punggung pada Operator Komputer Akibat Posisi dan Lama Duduk. Diakses tanggal 19 Mei 2015; http://www.mkbonline.org/web/index.php/MKB/article/ view/41/29.

[11] Tana, L., Delima, D., dan Tuminah, S., 2009. Hubungan Lama Kerja dan Posisi Kerja dengan Keluhan Otot Rangka Leher dan Ekremitas Atas pada Pekerja Garmen Perempuan di Jakarta Utara. Diakses tanggal 23 Februari 2013;

[12] http://ejournal.litbang.depkes.go.id/index.php/BPK/artic le/download/129/1492.

[13] Wasisto, S.W. 2005 , Komputer Secara Ergonomis dan Sehat . Diakses akses 17 November 2013; http://www.wahana.com .

Perundang undangan:

Undang - Uundang Nomor 13 Tahun 2003 tentang Ketenagakerjaan 